\title{
FH\&P RATING MODEL AND ITS APPLICATION WITHIN THE SLOVAK SPA ENTERPRISES
}

\author{
Veronika ČABINOVÁ* \\ University of Prešov in Prešov, Rectorate, Department of Development, \\ Informatization and Quality Assessment, Prešov, Slovakia, e-mail: veronika.cabinova@unipo.sk
}

\section{Jana BURGEROVÁ}

University of Prešov in Prešov, Faculty of Education, Department of Natural Sciences and Technological Disciplines, Prešov, Slovakia, e-mail: jana.burgerova@unipo.sk

\section{Peter GALLO}

University of Prešov in Prešov, Faculty of Arts, Institute of Educology and Social Work, Prešov, Slovakia, e-mail: peter.gallo.1@ unipo.sk

\author{
Citation: Čabinová, V., Burgerová, J., \& Gallo, P. (2021). FH\&P RATING MODEL AND ITS APPLICATION WITHIN THE \\ SLOVAK SPA ENTERPRISES. GeoJournal of Tourism and Geosites, 38(4), 1143-1150. https://doi.org/10.30892/gtg.38420-754
}

\begin{abstract}
The aim of the paper is to propose a suitable structure of the newly designed Financial Health \& Prediction (FH\&P) rating model, and by putting it into practice in Slovak spa enterprises, to contribute to the development of financial management concepts for spa facilities operating in the field of tourism. The quantification of individual dimensions of the FH\&P rating model was based on the calculation of selected ten key financial ratio indicators and prediction models. The values (in different units of measure) were converted to points using compiled transformation tables which formed the final score of the FH\&P rating model and subsequently the proposed A-FX rating. Based on the results, Kúpele Bojnice, Inc. (SE03), Špecializovaný liečebný ústav Marína, s.e. (SE21) and Kúpele Nimnica, Inc. (SE07) received the best rating. This innovative model provides financial managers actual, simple and understandable overview of the financial health of a spa company and its future financial perspective. With a several adjustments, the FH\&P rating model is easily applicable in any economic sector of Slovakia.
\end{abstract}

Key words: spa companies, Slovakia, tourism, financial health, financial prediction, transformation tables, model, final rating

$$
* \quad * \quad * * * *
$$

\section{INTRODUCTION}

Slovak spa enterprises are part of the public health care system. Currently, this system is under enormous pressure, mainly due to the trend of an aging population, rising health care costs and, last but not least, the COVID-19 pandemic.

Spa and health tourism has an irreplaceable role in the prevention of diseases. However, spa and medical care is important not only in terms of preventing the health of the population, but also in terms of the attractiveness of the destinations in which the spa is located. The spa and health tourism significantly contributes to the development of employment in the region, contributes to the revenues of national budgets and regional budgets, helps create the active balance of trade, contributes to the national GDP, improves the global reputation of the state, and above all it improves the health of the population, reducing incapacity for work and delaying disability. It is therefore important to pay attention to such type of tourism, especially by the tourism management organizations in the destinations. In today's hectic times, people are becoming increasingly aware of the importance of their health, and therefore the demand for spa products and active holidays is growing. Authors dealing with the issue of Slovak spas (e.g. Eliašová, 2009; Matlovičová et al., 2013; Kučerová and Marčeková, 2013; Gúčik, 2015; Marčeková et al., 2015; Gúčik et al., 2016; Šenková, 2017; Kerekeš, 2018) focus on its general characteristics, significance, strengths and weaknesses, position in the European context, method of financing, history of development, current trends, future direction, etc. The research significantly lacks quantification and evaluation of the financial situation of spa enterprises and prediction of their future financial prosperity. So far, no research studies aimed at creating a model diagnosing and predicting the performance of companies operating in the field of tourism in Slovak Republic have been recorded. Therefore, our ambition is to examine the development of financial health as well as future financial perspective of Slovak spa companies. The main aim of the paper is to propose a suitable structure of the newly designed Financial Health \& Prediction rating model (FH\&P rating model), and by putting it into practice in Slovak spa enterprises, to contribute to the development of management of business performance in tourism. The contribution of the paper is a comprehensive summary of significant results of the performed analyzes and the compilation of the rating of Slovak spa companies taking into account the analyzed aspects of financial health and prediction within the FH\&P rating model.

\section{LITERATURE REVIEW}

The spa enterprises also provide part of their services for tourism in case they provide services to visitors in their free time, for which they usually pay from their pensions. In a broader sense, spa tourism is included in health tourism. Several approaches to the classification of health tourism can be found in the literature. Most authors state that health tourism

\footnotetext{
* Corresponding author
} 
include spa tourism, wellness tourism and medical tourism (Attl, 2005; Gúčik, 2015). Health tourism services offer not only medical spas, but also wellness hotels and other tourism facilities in recreation centers, e. g. aqua parks with wellness services or hotels with wellness centers (Marčeková et al., 2015). However, the business environment is unattractive in the case of Slovak spa companies. The amount of financial support from the state is still declining, there are currently no investment incentives for spas. Frequent changes in the scope of state-funded health care are also a problem. The reduction of diagnoses in the indication list and the reimbursed stays related to them do not allow the implementation of long-term strategies for the development and thus increase the level of business uncertainty in the given area.

The spa enterprises focus primarily on spa treatment, but due to the decline in funding for spa treatment by health insurance companies, it is expanding the range of its services for self-payers. The primary goal is the prevention and treatment of diseases, the regeneration of body and relaxation with the use of the power of natural healing resources, the beauty of the natural environment and the composition of the cultural environment. The provision of spa services on the basis of natural healing resources and their appreciation is the essence of the business activities of spa enterprises.

The spa enterprise as a business entity is characterized by certain peculiarities, which result from the specific focus of its business activities (Eliašová, 2009). As stated by Dendiš (2002), the basic features of the spa company include:

- it provides mainly health care services, medical examinations, procedures and therapies, accommodation, catering, cultural, social and additional services,

- the provision of services is closely linked to the existence of natural medicinal resources, while the location and capacity of the company is influenced by the presence and abundance of the medicinal resource,

- the services forming the product of the spa company require a high proportion of live work,

- the professional and personal preconditions of the employees of the spa company have a significant impact on the final service and its quality,

- the high complexity of the services provided requires the provision of adequate infrastructure, and the need for large business capital is also related to this.

Gajdošík and Lencsésová (2015) add that the individual services should be coordinated so that they complement each other and enable maximum benefits to be achieved. Due to the rapidly changing global business environment, it is necessary to pay attention to the analysis of the financial situation of business entities and to develop new approaches and models predicting their future success. With the development of a market economy, the importance of financial analysis of a company is constantly increasing and financial criteria are becoming a crucial part of the formation of strategic goals (Goel, 2016). Financial analysis is used in the technical - quantitative analysis. In a broader sense, it is a tool that evaluates ongoing processes in the company. On the other hand, financial analysis can be specified as a tool to assess the development, financial health and current state of the company. The outputs of the financial analysis are crucial for future performance development (Palepu and Healy, 2013). Therefore, financial analysis forms the basis for strategic and financial planning. It is divided into two basic categories, namely ex post (deals with the control of the situation in which the company is in terms of financial and economic, taking into account past periods) and ex ante (applies the knowledge gained from the retrospective and predicts future development). Thanks to financial analysis, each company can be informed in detail and managed by processes that improve the individual components of its performance. It is the everincreasing competitive pressure that is forcing current entrepreneurs, managers and owners to make an increasing effort to control these processes and incorporate them into their business strategy (Brendea, 2014; Narkunienè and Ulbinaite, 2018). As various models for evaluating performance are currently being developed, in the paper we also tried to create a new approach that will be simple, innovative and beneficial for measuring and managing financial health and future perspective.

The financial situation of Slovak spa companies was (at least partially) analyzed by the authors Derco and Pavlišinová (2016). Derco (2017) followed up on the results of a previous study and examined the impact of the method of payment for spa care (self-paying, health insurance policyholders) on the financial situation and stability of Slovak companies in 20132016, based on three selected financial ratio indicators - Return on assets, Revenue growth rate and Net profit ratio. The author concluded that the financial stability of Slovak spa companies is based on the balance between the two groups of clients and the stagnant sales is one of the main factors that cause achieving below-average financial results in most spa companies. Litavcová et al. (2018) also evaluated the financial position of Slovak spa companies using selected multidimensional methods and subsequently multidimensional scaling. The basic evaluation criterion was the selection of key financial ratio indicators - Return on assets, Return on sales, the share of personnel costs in sales and the Ratio of value added to net turnover. Jenčová et al. (2019) followed up on the results of this study and examined the financial-economic analysis of spa enterprises using the identical financial indicators and four selected methods - ranking method, scoring method, standardized variable method, fictitious distance method. The results obtained in both research studies were almost identical.

\section{MATERIALS AND METHODS}

The research sample consisted of Slovak spa enterprises, which according to the statistical classification of economic activities of the Statistical Office of the Slovak Republic belong to section Q - Health and social work, division 89 - Health and specific subcategory 86909 - Other health care. Currently, only 28 enterprises operate in Slovakia in the field of providing spa care. Spa enterprises operate only in municipalities and cities with recognized spa status, which is granted by the Government of the Slovak Republic. A spa place represents the territory of a municipality or a part of the territory of a municipality which natural healing resources, natural healing spas, spa treatment centers and other facilities necessary for the performance of spa care are located. The vast majority of these spas are in domestic private ownership (64.29\%), followed by state ownership (25\%), international private ownership (7.14\%) and one spa is owned by associations, political 
parties and churches. However, 7 spa enterprises had to be excluded from the basic data set due to reported negative equity in the case of 2 enterprises and the existence of non-profit and contributory organizations, which could not be included in the analysis because of fundamental characteristics of financing and their legal framework. The resulting research sample consisted of a total of 21 spa enterprises: Bardejovské Kúpele, Inc. (SE01), Horezza, Inc. (SE02), Kúpele Bojnice, Inc. (SE03), Kúpele Dudince, Inc. (SE04), Kúpele Lučivná, Inc. (SE05), Kúpele Lúčky, Inc. (SE06), Kúpele Nimnica, Inc. (SE07), Kúpele Nový Smokovec, Inc. (SE08), Kúpele Sliač, Inc. (SE09), Kúpele Štós, Inc. (SE10), Kúpele Trenčianske Teplice, Inc. (SE11), Kúpele Vyšné Ružbachy, Inc. (SE12), Liečebné termálne kúpele, Inc. (SE13), Prírodné jódové kúpele Číž, Inc. (SE14), Slovenské Liečebné Kúpele Piešt’any, Inc. (SE15), Slovenské liečebné kúpele Rajecké Teplice, Inc. (SE16), Slovenské liečebné kúpele Turčianske Teplice, Inc. (SE17), Kúpele Horný Smokovec, Ltd. (SE18), Pieniny Resort, Ltd. (SE19), Slovthermae, Kúpele Diamant Dudince, s.e. (SE20), Špecializovaný liečebný ústav Marína, s.e. (SE21).

To quantify the ex post financial situation of spa enterprises, we used the 10 most used financial ratio indicators, which evaluate each important area of the financial situation - Current Liquidity (coefficient), Total Liquidity (coefficient), Asset Turnover (coefficient), Days Short-term Receivable Outstanding (days), Days Short-term Payable Outstanding (days), Total Indebtedness (\%), Interest Coverage Ratio (coefficient), Return On Assets (\%), Return On Equity $(\%)$ and Return On Sales (\%). Selected 10 prediction models were applied to quantify the ex ante financial prediction Quick Test, Doucha's Balance Analysis, Aspect Global Rating Model, Altman's Model (SR), Taffler's Model, Creditworthiness Index, Beerman's Model, Index IN05, Bilderbeek's Model and Poznański's Model. The initial scheme of the proposed model is illustrated in the following Figure 1. The overall process of creating an innovative FH\&P rating model

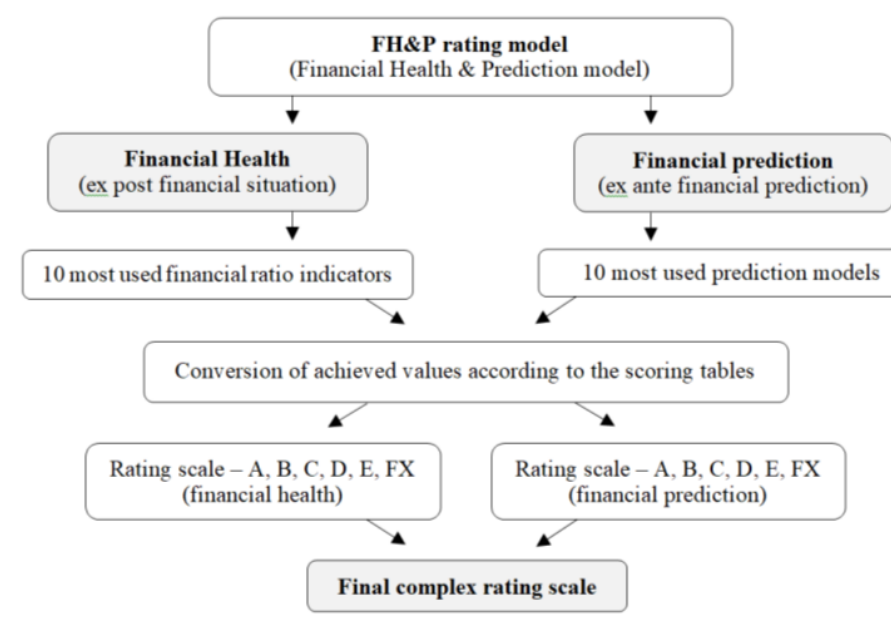

Figure 1. Initial scheme of the FH\&P rating model (Source: Own processing) can be briefly outlined in the following steps:

1. Based on the financial statements of the analysed spa enterprises, we quantified the values of selected 10 financial ratio indicators and 10 predictive models for the period under review (2015-2019).

2. Based on data from CRIF - Slovak Credit Bureau, Ltd., we designed transformation tables (see Table 1), where we created special ranges for individual financial ratio indicators and assigned points from 0 to 10 . The lower quartile of the indicator was assigned 0 points, the upper quartile 10 points. This rule was appropriate for indicators whose higher values reflect a better situation and their values should be generally increasing. In the case of indicators, the values of which should decrease, the upper and lower limits of the ranges were set exactly in reverse. The points were assigned to the indicator according to the range of their real value. We determined the boundaries of the individual margins by a simple recalculation (we divided it by the required number of categorization fields) and thus obtained a total of 6 margins with the number of points $10,8,6,4,2$ and 0 . In the case of predictive models, the margin limits were formed by generally recommended intervals indicating good or bad financial prospects of the company in the future (see Table 2). We repeated this procedure for each year of the analysed period.

3. Using the designed transformation tables, we subsequently assigned points to selected 10 financial ratio indicators and prediction models (separately for each year of the analysed period 2015-2019). Finally, we added up the achieved points for each indicator and prediction model and got one final score with a total range from 0 to 100 (a total of 10 indicators evaluated with a maximum of 10 points), separately within the evaluation of financial health and prediction (the $1^{\text {st }}$ and $3^{\text {rd }}$ step of the process was combined).

4. As the final score did not directly indicate the overall financial performance of the analysed spa enterprises, we created six categories with a rating from A to FX. The higher score reflected better financial health and its future prediction:

- $<100.00-83.33>\rightarrow$ perfect financial health $(\mathrm{A})$,

- $<83.32-66.66>\rightarrow$ an above-average financial health (B),

- $<66.65-49.98>\rightarrow$ average financial health (C),

- $<49.97-33.30>\rightarrow$ below-average financial health (D),

- $<33.29-16.63>\rightarrow$ bad financial health $(\mathrm{E})$,

- $<16.62-0.00>\rightarrow$ critical zone results (FX).

In the case of prediction models, the evaluation was set as follows:

- $<100.00-83.33>\rightarrow$ low probability of bankruptcy (A),

- $<83.32-66.66>\rightarrow$ below-average probability of bankruptcy (B),

- $<66.65-49.98>\rightarrow$ grey threat zone $(\mathrm{C})$,

- $<49.97-33.30>\rightarrow$ an above-average probability of bankruptcy (D),

- $<33.29-16.63>\rightarrow$ high probability of bankruptcy (E),

- $<16.62-0.00>\rightarrow$ critical zone results (FX). 
Table 1. Transformation table 1 - Financial ratio indicators (Source: Own calculation)

\begin{tabular}{|c|c|c|c|c|c|c|c|c|c|c|}
\hline Ratio indicator & \multicolumn{3}{|c|}{ Range of intervals } & \multirow{2}{*}{\begin{tabular}{|c|} 
Points \\
10 \\
\end{tabular}} & Ratio indicator & \multicolumn{3}{|c|}{ Range of intervals } & \multirow{2}{*}{$\begin{array}{c}\text { Points } \\
10\end{array}$} & \multirow{7}{*}{$\begin{array}{l}\text { Note: } \\
\text { * upper quartile values in } 2015 \\
\text { within the sector SK NACE } 86909\end{array}$} \\
\hline \multirow{6}{*}{$\begin{array}{l}\text { Current } \\
\text { Liquidity }\end{array}$} & & $>$ & $4.0100^{*}$ & & \multirow{6}{*}{$\begin{array}{c}\text { Total } \\
\text { Indebtedness }\end{array}$} & & $<$ & $21.8200 * *$ & & \\
\hline & 4.0099 & - & 3.1475 & 8 & & 21.8210 & - & 37.5450 & 8 & \\
\hline & 3.1474 & - & 2.2850 & 6 & & 37.5451 & - & 53.2700 & 6 & \\
\hline & 2.2849 & - & 1.4225 & 4 & & 53.2701 & - & 68.9950 & 4 & \\
\hline & 1.4224 & - & 0.5600 & 2 & & 68.9951 & - & 84.7200 & 2 & \\
\hline & & $<$ & $0.5600 * *$ & 0 & & & $>$ & $84.7200 *$ & 0 & \\
\hline \multirow{6}{*}{ Total Liquidity } & & $>$ & $4.1900 *$ & 10 & \multirow{6}{*}{$\begin{array}{c}\text { Interest } \\
\text { Coverage Ratio }\end{array}$} & & $>$ & $20.000 *$ & 10 & \multirow{7}{*}{$\begin{array}{l}* * \text { lower quartile values in } 2015 \\
\text { within the sector SK NACE } 86909 \\
\text { Interpretation of the results: } \\
<100.00-83.33>\rightarrow \text { perfect } \\
\text { financial health }(\mathrm{A}),\end{array}$} \\
\hline & 4.1899 & - & 3.2925 & 8 & & 19.999 & - & 14.7950 & 8 & \\
\hline & 3.2924 & - & 2.3950 & 6 & & 14.7949 & - & 9.5900 & 6 & \\
\hline & 2.3949 & - & 1.4975 & 4 & & 9.5899 & - & 4.3850 & 4 & \\
\hline & 1.4974 & - & 0.6000 & 2 & & 4.3849 & - & -0.8200 & 2 & \\
\hline & & $<$ & $0.6000 * *$ & 0 & & & $<$ & $-0.8200 * *$ & 0 & \\
\hline \multirow{6}{*}{ Asset Turnover } & & $<$ & $2.1700 * *$ & 10 & \multirow{6}{*}{$\begin{array}{l}\text { Return On } \\
\text { Assets }\end{array}$} & & $>$ & $22.5400 *$ & 10 & \\
\hline & 2.1699 & - & 1.7475 & 8 & & 22.5399 & - & 16.7525 & 8 & \multirow{5}{*}{$\begin{array}{l}<83.32-66.66>\rightarrow \text { an above- } \\
\text { average financial health }(\mathrm{B}), \\
<66.65-49.98>\rightarrow \text { average }\end{array}$} \\
\hline & 1.7474 & - & 1.3250 & 6 & & 16.7542 & - & 10.9650 & 6 & \\
\hline & 1.3249 & - & 0.9025 & 4 & & 10.9649 & - & 5.1775 & 4 & \\
\hline & 0.9024 & - & 0.4800 & 2 & & 5.1774 & - & -0.6100 & 2 & \\
\hline & & $>$ & $0.4800 *$ & 0 & & & $<$ & $-0.6100 * *$ & 0 & \\
\hline \multirow{6}{*}{$\begin{array}{c}\text { Days Short- } \\
\text { term Receivable } \\
\text { Outstanding }\end{array}$} & & $<$ & $32.0800 * *$ & 10 & \multirow{6}{*}{$\begin{array}{c}\text { Return On } \\
\text { Equity }\end{array}$} & & $>$ & $43.5100 *$ & 10 & \multirow{12}{*}{$\begin{array}{l}<49.97-33.30>\rightarrow \text { below- } \\
\text { average financial health }(\mathrm{D}), \\
<33.29-16.63>\rightarrow \text { bad } \\
\text { financial health }(\mathrm{E}), \\
<16.62-0.00>\quad \rightarrow \text { critical } \\
\text { zone results }(\mathrm{FX}) .\end{array}$} \\
\hline & 32.0801 & - & 50.6925 & 8 & & 43.5099 & - & 30.3900 & 8 & \\
\hline & \begin{tabular}{|l}
50.6926 \\
\end{tabular} & - & 69.3050 & 6 & & 30.3899 & - & 17.2700 & 6 & \\
\hline & \begin{tabular}{|l}
69.3051 \\
\end{tabular} & - & 87.9175 & 4 & & 17.2699 & - & 4.1500 & 4 & \\
\hline & 87.9176 & - & 106.5300 & 2 & & 4.1499 & - & -8.9700 & 2 & \\
\hline & & $>$ & 106.5300* & 0 & & & $<$ & $-8.9700 * *$ & 0 & \\
\hline \multirow{6}{*}{$\begin{array}{l}\text { Days Short- } \\
\text { term Payable } \\
\text { Outstanding }\end{array}$} & & $<$ & $46.6900 * *$ & 10 & \multirow{6}{*}{$\begin{array}{l}\text { Return On } \\
\text { Sales }\end{array}$} & & $>$ & $19.4600 *$ & 10 & \\
\hline & 46.6901 & - & 113.2050 & 8 & & 19.4599 & $\begin{array}{lll}- & \\
-\end{array}$ & 14.6300 & 8 & \\
\hline & 113.2051 & - & 179.7200 & 6 & & 14.6299 & - & 9.8000 & 6 & \\
\hline & \begin{tabular}{|l|}
179.7201 \\
\end{tabular} & & 246.2350 & 4 & & 9.7999 & - & 4.9700 & 4 & \\
\hline & 246.2351 & - & 312.7500 & 2 & & 4.9699 & - & 0.1400 & 2 & \\
\hline & & $>$ & 312.7500* & 0 & & & $<$ & $0.1400 * *$ & 0 & \\
\hline
\end{tabular}

Table 2. Transformation table 2 - Prediction models (Source: Own calculation)

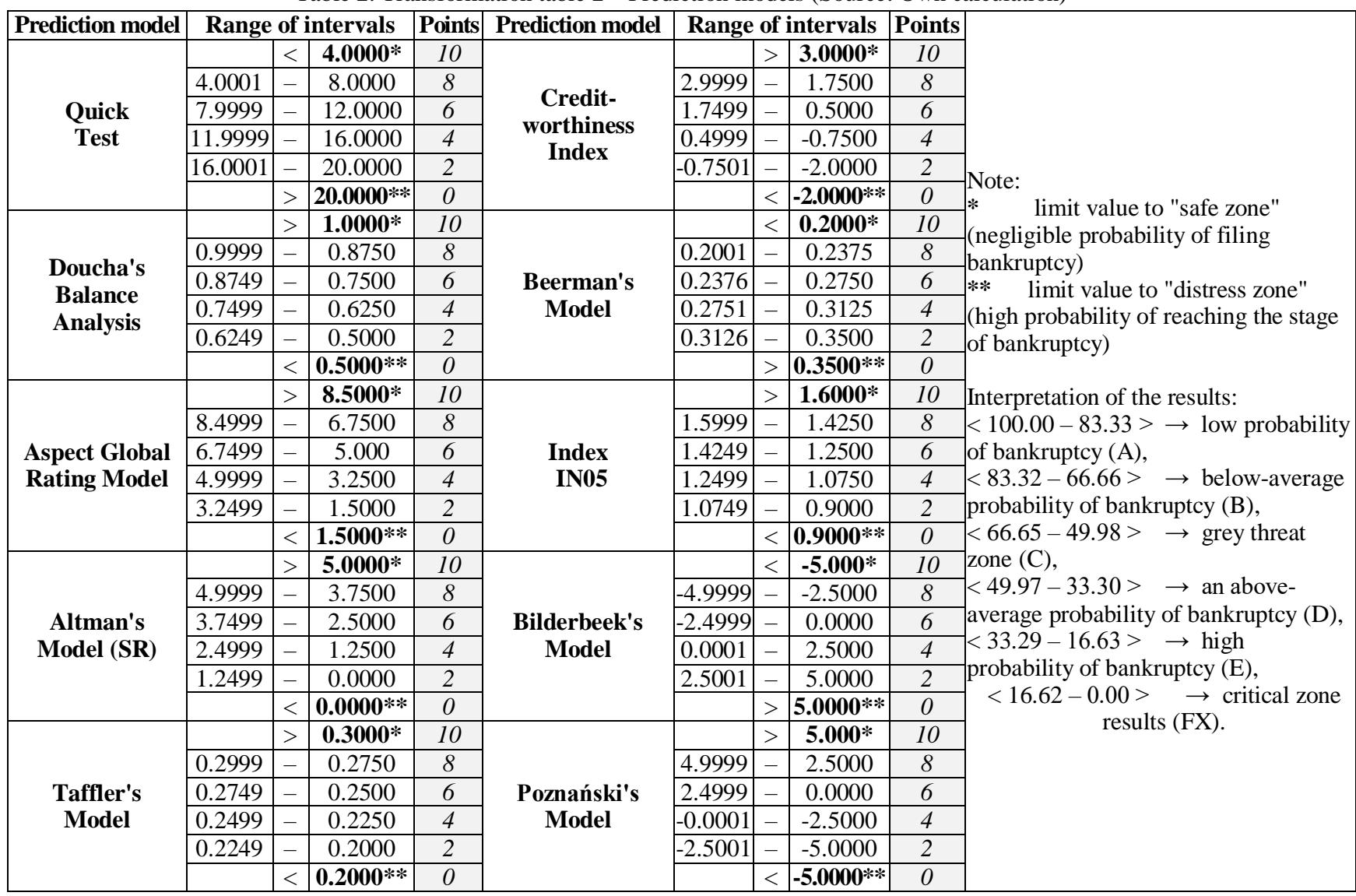

The result of the created FH\&P rating model is a final A-FX rating summarizing the current and future state of the financial situation of spa companies and recommending the application of appropriate corrective measures in time. 
The data were obtained from the financial statements of spa enterprises from a publicly available portal managed by DataSpot, Ltd. When processing the scoring tables for individual financial ratio indicators within our proposal, we used data (upper and lower quartile of these indicators within the specific subcategory 86909 - Other health care) provided by CRIF - Slovak Credit Bureau, Ltd. All calculations, graphs and tables were processed in MS Excel.

\section{RESULTS AND DISCUSSION}

The quantification of the final score was preceded by a number of detailed calculations, which were realized in the MS Excel for the subsequent practical availability of the research. The first step in calculating the score of the FH\&P rating model was to quantify the values of selected financial ratio indicators, for each enterprise (21 spa enterprises) and each year (5 years) of the analyzed period 2015-2019. No outliers were identified in the data file. According to the description of the $2^{\text {nd }}$ step given in the previous chapter, a transformation table 1 (see Annex 1) was subsequently designed using the upper and lower quartiles for the corresponding tourism sector and thus assigned the appropriate number of points to the individual indicators. Due to the limited scope of the paper, the following Table 3 illustrates an example of this conversion in the case of the first analyzed spa company Bardejovské Kúpele, Inc. (SE01).

Table 3. Conversion of financial indicator values into points based on the designed Transformation table 1 - an example of Bardejovské Kúpele, Inc. (SE01) (Source: Own calculation)

\begin{tabular}{|l|c|c|c|c|c|}
\hline \multirow{2}{*}{ Financial ratio indicators } & $\mathbf{2 0 1 5}$ & $\mathbf{2 0 1 6}$ & $\mathbf{2 0 1 7}$ & $\mathbf{2 0 1 8}$ & $\mathbf{2 0 1 9}$ \\
\cline { 2 - 6 } & Value (points) & Value (points) & Value (points) & Value (points) & Value (points) \\
\hline Current Liquidity & $1.05(2)$ & $0.88(2)$ & $0.82(2)$ & $0.64(0)$ & $0.80(2)$ \\
\hline Total Liquidity & $1.08(2)$ & $0.92(2)$ & $0.85(2)$ & $0.67(0)$ & $0.83(2)$ \\
\hline Asset Turnover & $0.60(2)$ & $0.70(2)$ & $0.74(2)$ & $0.82(2)$ & $0.92(4)$ \\
\hline Days Short-term Receivable Outstanding & $110.69(0)$ & $61.40(4)$ & $58.65(4)$ & $53.61(4)$ & $41.69(6)$ \\
\hline Days Short-term Payable Outstanding & $107.41(8)$ & $72.03(8)$ & $74.74(8)$ & $88.85(8)$ & $77.95(8)$ \\
\hline Total Indebtedness & $29.94(8)$ & $31.20(8)$ & $29.41(8)$ & $25.93(8)$ & $26.26(8)$ \\
\hline Interest Coverage Ratio & $10.39(6)$ & $4.79(4)$ & $9.07(4)$ & $15.11(8)$ & $25.62(10)$ \\
\hline Return On Assets & $7.49(4)$ & $3.29(2)$ & $5.38(2)$ & $8.18(4)$ & $9.42(4)$ \\
\hline Return On Equity & $7.39(4)$ & $2.75(2)$ & $5.24(4)$ & $8.07(4)$ & $9.21(4)$ \\
\hline Return On Sales & $8.68(4)$ & $2.72(2)$ & $4.97(4)$ & $7.31(4)$ & $7.40(4)$ \\
\hline Total score & $\mathbf{4 0}$ & $\mathbf{3 6}$ & $\mathbf{4 0}$ & $\mathbf{4 2}$ & $\mathbf{5 2}$ \\
\hline A-FX rating & $\mathrm{D}$ & $\mathrm{D}$ & $\mathrm{D}$ & $\mathrm{D}$ & $\mathrm{C}$ \\
\hline
\end{tabular}

The development of individual financial indicators has not changed significantly over the analysed years. The most significant positive development was recorded in the case of the Day Short-term Receivable Outstanding, as the values of this indicator decreased by almost two thirds and the total score increased by 6 points. Despite the values in 2016 and 2017 , we also note a positive development in the case of the Interest Coverage Ratio reaching the maximum possible number of points (10). The most critical values were achieved in the case of liquidity and profitability indicators, which was identified as the most common weakness of almost every Slovak spa company. With the exception of 2016, the total score reached in the case of the FH dimension showed a positive growing trend; the most significant increase was recorded in the last 2 years of the analyzed period, when the liquidity level returned to the baseline values. Overall, the rating of this dimension has improved from D to C, i.e. the enterprise with average financial health within the corresponding tourism sector.

The identical process was applied in the case of the FP dimension reflecting possible financial problems, instability or bankruptcy of the company. The limit values of the designed scales formed the generally recommended values of individual prediction models. However, the values of the upper and lower quartiles were not available. The CRIF - Slovak Credit Bureau, Ltd. does not keep any records of the above-mentioned data, as many Slovak companies pay almost no attention to this area and manage their business activities only intuitively. The results obtained in the case of the spa company Bardejovské Kúpele, Inc. (SE01) are shown in the following Table 4.

Table 4. Conversion of prediction model values into points based on the designed Transformation table 2 - an example of Bardejovské Kúpele, Inc. (SE01) (Source: Own calculation)

\begin{tabular}{|l|c|c|c|c|c|}
\hline \multirow{2}{*}{\multicolumn{1}{c|}{ Prediction models }} & $\mathbf{2 0 1 5}$ & $\mathbf{2 0 1 6}$ & $\mathbf{2 0 1 7}$ & $\mathbf{2 0 1 8}$ & $\mathbf{2 0 1 9}$ \\
\cline { 2 - 6 } & Value (points) & Value (points) & Value (points) & Value (points) & Value (points) \\
\hline Quick Test & $7(8)$ & $9(6)$ & $7(8)$ & $6(8)$ & $6(8)$ \\
\hline Doucha's Balance Analysis & $0.58(2)$ & $0.39(0)$ & $0.46(0)$ & $1.34(10)$ & $1.40(10)$ \\
\hline Aspect Global Rating Model & $4.68(4)$ & $3.78(4)$ & $4.20(4)$ & $4.79(4)$ & $5.23(6)$ \\
\hline Altman's Model (SR) & $0.58(2)$ & $0.63(2)$ & $0.67(2)$ & $0.72(2)$ & $0.83(2)$ \\
\hline Taffler's Model & $0.43(10)$ & $0.32(10)$ & $0.39(10)$ & $0.45(10)$ & $0.52(10)$ \\
\hline Credit-worthiness Index & $2.13(8)$ & $1.18(6)$ & $1.66(6)$ & $2.31(8)$ & $2.54(8)$ \\
\hline Beerman's Model & $0.04(10)$ & $0.06(10)$ & $0.06(10)$ & $0.01(10)$ & $0.00(10)$ \\
\hline Index IN05 & $1.37(6)$ & $0.97(2)$ & $1.25(6)$ & $1.66(10)$ & $2.16(10)$ \\
\hline Bilderbeek's Model & $-2.46(6)$ & $-2.25(6)$ & $-2.08(6)$ & $-1.86(6)$ & $-1.85(6)$ \\
\hline Poznański's Model & $3.78(8)$ & $3.16(8)$ & $3.27(8)$ & $3.25(8)$ & $3.42(8)$ \\
\hline Total score & $\mathbf{6 4}$ & $\mathbf{5 4}$ & $\mathbf{6 0}$ & $\mathbf{7 6}$ & $\mathbf{7 8}$ \\
\hline A-FX rating & $\mathrm{C}$ & $\mathrm{C}$ & $\mathrm{C}$ & $\mathrm{B}$ & $\mathrm{B}$ \\
\hline
\end{tabular}


Based on the achieved total score in the case of the FP dimension, the spa company SE01 recorded significantly better results. Even the lowest total score recorded in 2016 exceeded the maximum score achieved in the case of the $\mathrm{FH}$ dimension. Taffler's Model and Beerman's Model evaluated the future financial prosperity of the company by up to 10 points each year. In the last 2 years of the analyzed period, this fact was also confirmed by Doucha's Balance Analysis and Index IN05. Serious financial problems of the enterprise were expected in the case of the application Altman's Model (SR), which is given significant importance. This model is based on the original Altman's Model, however, the weights of individual indicators have been adjusted with respect to the specifics of the business environment of the Slovak Republic. In recent years, many Slovak authors have tried to take into account these specifics and thus design predictive models reflecting reality better than models designed abroad. Each of them reflected the specific conditions of a given economy in a given period of time, which reduces their relevance and applicability in the conditions of Slovak Republic. Overall, the spa company SE01, recorded a positive growing trend of the total score (the only exception was 2016). Over the years, the rating of this dimension has improved from $\mathrm{C}$ to $\mathrm{B}$, i.e. the enterprise is only threatened by below-average probability of bankruptcy.

The result of the application of this process for each spa enterprise included in the research sample is summarized in Table 5 below. Thus, individual spas have the opportunity to monitor the development of their financial health and future financial prosperity since 2015. They can focus mainly on the trend of recent years indicating its current financial condition and performance. During the analyzed years, the dimension of financial health (FH) of each spa company achieved on average 1.33 points more than in the base year 2015. The most significant improvement was identified in the case of Kúpele Nimnica, Inc. (SE07), whose final score increased every year (a total of 28 points). The sharp increase in the last year was mainly due to the improvement in the values of the company's liquidity financial indicators. During the years analyzed, Pieniny Resort, Ltd. (SE19) recorded the most significant deterioration of its financial health, as its final score fell from 22 to 6. Despite fluctuating developments, a total of 4 spa enterprises - Kúpele Lučivná, Inc. (SE05), Kúpele Nový Smokovec, Inc. (SE08), Kúpele Sliač, Inc. (SE09) and Slovenské liečebné kúpele Rajecké Teplice, Inc. (SE16) achieved the same final score at the end of 2019 compared to the base year.

In the case of evaluating the dimension of the financial prediction (FP), the achieved values were much more acceptable as each spa enterprise improved its future financial prediction by an average of 7.14 points. The most significant improvement in the financial perspective reached Kúpele Trenčianske Teplice, Inc. (SE11), whose final score increased by 32 points compared to the base year. Deterioration of the overall assessment of the given dimension was recorded in the case of only 5 spa enterprises, which can be assessed quite positively. The most significant decrease (by a total of 20 points) was recorded by Liečebné termálne kúpele, Inc. (SE13), 2 spa enterprises kept the same final score Kúpele Bojnice, Inc. (SE03) and Slovenské liečebné kúpele Turčianske Teplice, Inc. (SE17).

Table 5. Development of scores achieved based on the application of the designed transformation tables

1 and 2 over the years 2015-2019 (Source: Own calculation)

\begin{tabular}{|c|c|c|c|c|c|c|c|c|c|c|c|c|}
\hline Spa & \multicolumn{9}{|c|}{ Financial health (FH) } & \multicolumn{5}{|c|}{ Financial prediction (FP) } \\
\cline { 2 - 15 } enterprises & $\mathbf{2 0 1 5}$ & $\mathbf{2 0 1 6}$ & $\mathbf{2 0 1 7}$ & $\mathbf{2 0 1 8}$ & $\mathbf{2 0 1 9}$ & $\downarrow \uparrow$ & $\mathbf{2 0 1 5}$ & $\mathbf{2 0 1 6}$ & $\mathbf{2 0 1 7}$ & $\mathbf{2 0 1 8}$ & $\mathbf{2 0 1 9}$ & $\downarrow \uparrow$ \\
\hline SE01 & 40 & 36 & 40 & 42 & 52 & $\uparrow \mathbf{1 2}$ & 64 & 54 & 60 & 76 & 78 & $\uparrow \mathbf{1 4}$ \\
\hline SE02 & 50 & 36 & 34 & 60 & 42 & $\downarrow \mathbf{8}$ & 64 & 38 & 26 & 76 & 74 & $\uparrow \mathbf{1 0}$ \\
\hline SE03 & 70 & 72 & 70 & 70 & 68 & $\downarrow \mathbf{2}$ & 86 & 86 & 86 & 86 & 86 & - \\
\hline SE04 & 46 & 44 & 48 & 48 & 50 & $\uparrow \mathbf{4}$ & 54 & 58 & 58 & 70 & 76 & $\uparrow \mathbf{2 2}$ \\
\hline SE05 & 26 & 32 & 32 & 38 & 26 & - & 48 & 34 & 42 & 58 & 40 & $\downarrow \mathbf{8}$ \\
\hline SE06 & 42 & 46 & 44 & 36 & 44 & $\uparrow \mathbf{2}$ & 64 & 64 & 60 & 50 & 68 & $\uparrow \mathbf{4}$ \\
\hline SE07 & 52 & 58 & 64 & 68 & 80 & $\uparrow \mathbf{2 8}$ & 56 & 66 & 74 & 86 & 80 & $\uparrow \mathbf{2 4}$ \\
\hline SE08 & 40 & 40 & 40 & 44 & 40 & - & 56 & 50 & 48 & 58 & 64 & $\uparrow \mathbf{8}$ \\
\hline SE09 & 32 & 28 & 24 & 28 & 32 & - & 20 & 20 & 20 & 18 & 18 & $\downarrow \mathbf{2}$ \\
\hline SE10 & 34 & 34 & 20 & 28 & 36 & $\uparrow \mathbf{2}$ & 48 & 52 & 22 & 30 & 56 & $\uparrow \mathbf{8}$ \\
\hline SE11 & 40 & 42 & 42 & 46 & 50 & $\uparrow \mathbf{1 0}$ & 42 & 46 & 48 & 60 & 74 & $\uparrow \mathbf{3 2}$ \\
\hline SE12 & 22 & 28 & 26 & 26 & 28 & $\uparrow \mathbf{6}$ & 38 & 40 & 44 & 48 & 52 & $\uparrow \mathbf{1 4}$ \\
\hline SE13 & 22 & 34 & 20 & 16 & 14 & $\downarrow \mathbf{8}$ & 44 & 38 & 24 & 20 & 24 & $\downarrow \mathbf{2 0}$ \\
\hline SE14 & 24 & 20 & 18 & 20 & 32 & $\uparrow \mathbf{8}$ & 36 & 20 & 22 & 18 & 48 & $\uparrow \mathbf{1 2}$ \\
\hline SE15 & 50 & 42 & 44 & 52 & 48 & $\downarrow \mathbf{2}$ & 64 & 48 & 64 & 74 & 70 & $\uparrow \mathbf{6}$ \\
\hline SE16 & 48 & 58 & 44 & 40 & 48 & - & 68 & 70 & 64 & 72 & 84 & $\uparrow \mathbf{1 6}$ \\
\hline SE17 & 40 & 38 & 26 & 26 & 44 & $\uparrow \mathbf{4}$ & 58 & 46 & 38 & 32 & 58 & - \\
\hline SE18 & 46 & 54 & 60 & 56 & 54 & $\uparrow \mathbf{8}$ & 58 & 66 & 84 & 82 & 82 & $\uparrow \mathbf{2 4}$ \\
\hline SE19 & 22 & 20 & 22 & 16 & 6 & $\downarrow \mathbf{1 6}$ & 28 & 46 & 32 & 36 & 36 & $\uparrow \mathbf{8}$ \\
\hline SE20 & 58 & 56 & 60 & 48 & 46 & $\downarrow \mathbf{1 2}$ & 82 & 70 & 82 & 62 & 64 & $\downarrow \mathbf{1 8}$ \\
\hline SE21 & 66 & 66 & 62 & 60 & 58 & $\downarrow \mathbf{8}$ & 86 & 86 & 84 & 84 & 82 & $\downarrow \mathbf{4}$ \\
\hline & & & & & & & & & & \\
\hline
\end{tabular}

Table 6. Final ranking of Slovak spa companies based on the application of the FH\&P rating model - average data over the years 2015-2019 (Source: Own calculation)

\begin{tabular}{|c|c|c|c|c|c|c|}
\hline \multirow{2}{*}{$\begin{array}{l}\text { Spa } \\
\text { enter- } \\
\text { prises }\end{array}$} & \multirow[t]{2}{*}{ Rank } & \multicolumn{2}{|c|}{ Scores } & \multirow{2}{*}{$\begin{array}{c}\text { FH\&P } \\
\text { (average of FH } \\
\text { and FP scores) }\end{array}$} & \multicolumn{2}{|c|}{$\begin{array}{l}\text { A-FX } \\
\text { rating }\end{array}$} \\
\hline & & $\mathrm{FH}$ & FP & & FH & FP \\
\hline SE03 & 1. & 70 & 86 & 78 & $\mathrm{~B}$ & A \\
\hline SE21 & 2. & 62 & 84 & 73 & $\mathrm{C}$ & $\mathrm{A}$ \\
\hline SE07 & 3. & 64 & 72 & 68 & $\mathrm{C}$ & B \\
\hline SE18 & 4. & 54 & 74 & 64 & $\mathrm{C}$ & $\mathrm{B}$ \\
\hline SE20 & 5. & 54 & 72 & 63 & $\mathrm{C}$ & $\mathrm{B}$ \\
\hline SE16 & 6. & 48 & 72 & 60 & $\mathrm{D}$ & B \\
\hline SE15 & 7. & 47 & 64 & 56 & $\mathrm{D}$ & $\mathrm{C}$ \\
\hline SE04 & 8. & 47 & 63 & 55 & $\mathrm{D}$ & $\mathrm{C}$ \\
\hline SE01 & 9. & 42 & 66 & 54 & $\mathrm{D}$ & $\mathrm{C}$ \\
\hline SE06 & 10. & 42 & 61 & 52 & $\mathrm{D}$ & $\mathrm{C}$ \\
\hline SE02 & 11. & 44 & 56 & 50 & $\mathrm{D}$ & $\mathrm{C}$ \\
\hline SE11 & 12. & 44 & 54 & 49 & $\mathrm{D}$ & $\mathrm{C}$ \\
\hline SE08 & 13. & 41 & 55 & 48 & $\mathrm{D}$ & $\mathrm{C}$ \\
\hline SE17 & 14. & 35 & 46 & 41 & $\mathrm{D}$ & $\mathrm{D}$ \\
\hline SE05 & 15. & 31 & 44 & 38 & $\mathrm{E}$ & $\mathrm{D}$ \\
\hline SE10 & 16. & 30 & 42 & 36 & $\mathrm{E}$ & D \\
\hline SE12 & 17. & 26 & 44 & 35 & $\mathrm{E}$ & $\mathrm{D}$ \\
\hline SE19 & 18. & 17 & 36 & 26 & $\mathrm{E}$ & D \\
\hline SE14 & 19. & 23 & 29 & 26 & $\mathrm{E}$ & $E$ \\
\hline SE13 & 20. & 21 & 30 & 26 & $E$ & $\mathrm{E}$ \\
\hline SE09 & 21. & 29 & 19 & 24 & $\mathrm{E}$ & $\mathrm{E}$ \\
\hline
\end{tabular}

Thanks to this simple recalculation, spa enterprises also have the opportunity to monitor and compare their results with their biggest competitors operating in the corresponding tourism sector. The final ranking of individual spa enterprises, which was compiled as an average of the FH\&P score achieved over the years 2015-2019, is presented in Table 6. Spa enterprises are ranked in ascending order, from best to worst rated. The average score was quantified for both dimensions of the FH\&P rating model and the final ranking of enterprises was compiled on the basis of the average 
of these values. Thanks to transformation tables 1 and 2, the individual dimensions (FH and FP) were assigned an A-FX rating, which significantly facilitates the interpretation of many performed calculations. Of course, the classification of a company in the A-FX rating category corresponds to its final score.

Based on the results presented in Table 6, the best average results in both monitored dimensions of the FH\&P rating model was reached by Kúpele Bojnice, Inc. (SE03) with a final BA rating. In order for a company to be assigned to A rating category within the $\mathrm{FH}$ dimension, it would have to focus on increasing the Asset Turnover, Interest Coverage and all profitability indicators, as they recorded the average values within the given tourism sector. The second best rated spa enterprise is Špecializovaný liečebný ústav Marína, s.e. (SE21) with a final CA rating. Within the FP dimension, this state enterprise achieved the second highest total score, but on the basis of the compiled FH\&P rating model, Kúpele Nimnica, Inc. (SE07) achieved a better level of financial health and ranked $3^{\text {rd }}$ with a final CB rating. Financial health weaknesses of Špecializovaný liečebný ústav Marína, s.e. (SE21) are almost identical to Kúpele Bojnice, Inc. (SE03), but also all Slovak spa companies. However, the problems with low profitability, production power and insufficient appreciation of invested funds are deepened by the current COVID-19 pandemic.

The worst results were recorded in the case of Prírodné jódové kúpele Číž, Inc. (SE14), Liečebné termálne kúpele, Inc. (SE13) and Kúpele Sliač, Inc. (SE09). The final rating (EE) of these spa enterprises pointed to the critical results achieved in the case of both evaluated dimensions of the FH\&P rating model. The analyzed spa enterprises did not have sufficient funds to cover short-term liabilities, so they should reduce the level of their short-term liabilities in order to achieve optimal values of liquidity ratios. The causes of deteriorating performance and future prosperity in most Slovak spa enterprises can be found in several areas, not just in the financial one. However, the enterprises are able to influence their financial health mainly by own business activity, so it is very important to focus on achieving a profit in a sufficient amount to improve the overall financial performance. One of the ways how to reach this goal can also be investment into tourist infrastructure, accommodation, sport or cultural facilities.

\section{LIMITATIONS OF THE STUDY}

One of the most significant limits of the study is the size of the research sample. As there are only 30 spa enterprises operating in Slovakia with the official permit of the Ministry of Health of the Slovak Republic, it was not possible to influence the given fact in any way. Another limitation of the study is the specific data provided in the case of the upper and lower quartiles of financial indicators. The CRIF - Slovak Credit Bureau, Ltd. does not maintain a database of the mean values of all financial indicators, but only the selected ones. Therefore, the achieved rating of spa enterprises depended especially on selected indicators; in the case of the selection of other variables, different results would probably be achieved. However, this limitation goes beyond the scope of this paper, but also creates space for further research.

Another limit of the study is the focus on Slovak spa companies exclusively. It would be interesting to extend the research sample to other European countries and to observe how the position of the Slovak spas will change, as well as the ranking rating of individual Slovak spa enterprises in the context of international comparisons.

\section{CONCLUSION}

It is widely recognised that the ever-changing ways of life of modern society increasingly draws the attention to the beneficial effects of healthy lifestyle (Hushko et al., 2021). Beyond the treatment of the already evolved diseases, an increasing focus is on prevention organically contributing health tourism to become an independent tourism product, however, the global tourism industry keeps count of it as a niche product (Nahrstedt, 2004; Hopkins et al., 2010; Aubert et al., 2012).

Many enterprises operating in tourism underestimate the importance of well-processed financial analysis and are not aware of its significant impact on the overall financial management of the company in today's difficult competitive environment. Financial managers often have a problem with interpretation of the results, comparing them with the recommended values or optimal intervals indicated in the literature that do not reflect the conditions of current practice. Therefore, companies operating in the tourism industry often resort to intuitive management of their finances and pay particular attention to non-financial indicators such as customer satisfaction, quality of services provided, innovations, employee turnover, etc. It is important to maintain a healthy balance between these groups of indicators and not to give priority to monitoring exclusively non-financial metrics under the pressure from consultants, training or publications on modern management. Measuring the financial performance and future prosperity of the tourism enterprises is essential, regarding the current pandemic situation. In such context, improving their financial situation and the competitive position also depend on the use of the innovative multi-criteria evaluation methods and models.

Therefore, the aim of this research paper was to design an innovative FH\&P rating model, describe the methodology for calculating its final score and, based on the created A-FX rating, to provide financial managers a simple and understandable overview of financial health and future financial perspective of a company.

During the analyzed period 2015-2019, the best average results were achieved by Kúpele Bojnice, Inc. (SE03), Špecializovaný liečebný ústav Marína, s.e. (SE21) and Kúpele Nimnica, Inc. (SE07) which thus became the benchmarks of the given tourism industry. A significant strengthening of the competitive position was also recorded in the case of Kúpele Trenčianske Teplice, Inc. (SE11) and Kúpele Horný Smokovec, Ltd. (SE18). Overall, the worst results were reached by Prírodné jódové kúpele Č́íž, Inc. (SE14), Liečebné termálne kúpele, Inc. (SE13) and Kúpele Sliač, Inc. (SE09). Their final rating (EE) pointed to the critical results achieved in both evaluated dimensions of the FH\&P rating model.

Based on the application of the proposed process for calculating the FH\&P score, Slovak spa enterprises are able to monitor the development of their financial health and the future financial perspective. 
In addition, by processing a summary final ranking with the results of all Slovak spa enterprises, they can compare their results with their biggest competitors operating in the corresponding tourism sector, identify their strengths and weaknesses and use them in forming the future financial management strategy.

\section{ACKNOWLEDGEMENT}

This paper is supported by the project GaPU 14/2021 - "FH\&P Rating Model and its Application within the Slovak Spa Enterprises".

\section{REFERENCES}

Attl, P. (2005). K pojetí lázeňství [The Concept of Spas]. Institute of Hospitality Management in Prague, Prague, Czech Republic. Czech Hospitality and Tourism Papers, 1(1), 43-67.

Aubert, A., Jónás-Berki, M., \& Marton, G. (2012). Spatial Organisation and Management Characteristics of Health Tourism in Hungary. Central European Regional Policy and Human Geography, 2(2), 27-36. https://regi.tankonyvtar.hu/hu/tartalom/ tamop422b/20100029_kotet_19_019_19/019_19.pdf

Brendea, G. (2014). Financing Behaviour of Romanian Listed Firms in Adjusting to the Target Capital Structure. Czech Journal of Economics and Finance, 64(4), 312-329. https://journal.fsv.cuni.cz/storage/1304_312-329_-_brendea.pdf

Dendiš, L. (2002). Kúpel'níctvo, kúpel'né služby a kúpel'ný podnik [Spa, Spa Services and Spa Business]. In Zborník výsledkov výskumu katedry služieb a cestovného ruchu obchodnej fakulty ekonomickej univerzity projektov Vega a inštitucionálnych projektov [Proceedings of the Research Results of the Department of Services and Tourism, Faculty of Business, University of Economics, Vega Projects and Institutional Projects] (pp. 295-296). University of Economics in Bratislava, Bratislava, Slovak Republic.

Derco, J., \& Pavlišinová, D. (2016). Financial Position of Medical Spas - The Case of Slovakia. Tourism Economics, 23(4), 867-873. https://doi.org/10.5367/te.2016.0553

Derco, J. (2017). Impact of Health Care Funding on Financial Position of Slovak Medical Spas. Tourism: An International Interdisciplinary Journal, 65(3), 376-380. https://hrcak.srce.hr/186960

Eliašová, D. (2009). Slovenské kúpel'níctvo v 20. storoči [Slovak spa in the 20 century], Ekonóm, Bratislava, Slovak Republic.

Gajdošík, T., \& Lencsésová, Z. (2015). Ekonomické účinky kúpelných podnikov [Economic Impacts of Spa Businesses on Tourism Destination]. Matej Bel University, Banská Bystrica, Slovak Republic. Folia Turistica 5, $2015(1), 39-47$. https://hugepdf.com/download/folia-turistica-5_pdf

Goel, S. (2016). Financial Ratios, Business Expert Press, New York, USA.

Gúčik, M. (2015). Zdravotný cestovný ruch ako prejav zdravotného uvedomenia obyvatelstva [Health Tourism as a Sign of Health Awareness of Population]. Matej Bel University, Banská Bystrica, Slovak Republic. Folia Turistica 5, $2015(1)$, 54-61. https://hugepdf.com/download/folia-turistica-5_pdf

Gúčik, M., Kvasnová, D., \& Pančíková, K. (2016). Medical Spa versus Health Tourism. Acta Academica Karviniensia, 16, 5-15. http://dx.doi.org/10.25142/aak.2016.010

Hopkins, L., Labonté, R., Runnels, V., \& Packer, C. (2010). Medical Tourism Today: What is the State of Existing Knowledge? Journal of Public Health Policy, 31(2), 185-198. http://dx.doi.org/10.1057/jphp.2010.10

Hushko, S., Kulishov, V., Hangoni, T., Puriy, H., Kuzyšin, B., \& Šip, M. (2021). Global Work Mobility in the Integration Conditions. Quality-Access to Success, 22(183), 72-77. https://www.proquest.com/docview/2549088624?pq-origsite=gscholar\&fromopenview=true

Jenčová, S., Vašaničová, P., \& Petruška, I. (2019). Financial Position of the Slovak Spa Companies. 16 ${ }^{\text {th }}$ Annual International Scientific Conference on European Financial Systems, Masaryk University, Brno, Czech Republic, 24-25 ${ }^{\text {th }}$ June 2019, 218-225.

Kerekeš, J. (2018). Kúpelníctvo a jeho význam v turizme. [Spa and its Importance in Tourism], Weltprint, Bratislava, Slovak Republic.

Kučerová, J., \& Marčeková, R. (2013). Inovácie vo vybraných kúpelných miestach na Slovensku [Innovations in Selected Spa Places in Slovakia]. Matej Bel University, Banská Bystrica, Slovak Republic. Folia Turistica 3, 2013(1), 68-78.

Litavcová, E., Jenčová, S., Košíková, M., \& Šenková, A. (2018). Implementation of Multidimensional Analytical Methods to Compare Performance between Spa Facilities. 12 ${ }^{\text {th }}$ International Days of Statistics and Economics, Melandrium, Prague, Czech Republic, 6-8 September 2018, 1070-1079.

Marčeková, R., Šebová, L', \& Galvánková, L. (2015). Aktívne starnutie populácie ako príležitost pre rozvoj zdravotného cestovného ruchu na Slovensku [Active Aging of Population as an Opportunity for the Development of Health Tourism in Slovakia]. Matej Bel University, Banská Bystrica, Slovak Republic. Folia Turistica 5, 2015(1), 54-61. https://hugepdf.com/download/folia-turistica-5_pdf

Matlovičová, K., Kolesarová, J., \& Židová, A. (2013). Slovenské kúpel'níctvo v kontexte zmien - aktuálny stav, problémy a výzvy [Slovak Spas in the Context of Change - Current Conditions, Issues and Challenges]. In Recreational Use of Geothermal Water in Visegrad Group Countries (pp. 161-173). Institute of Urban Development, Krakow, Poland.

Nahrstedt, W. (2004). Wellness: A New Perspective for Leisure Centers, Health Tourism, and Spas in Europe on the Global Health Market. In The Tourism and Leisure Industry: Shaping the Future (pp. 181-198). Haworth Hospitality Press, Binghamton, USA.

Narkunienè, J., \& Ulbinaite, A. (2018). Comparative Analysis of Company Performance Evaluation Methods. Entrepreneurship and Sustainability Issues, 6(1), 125-138. https://doi.org/10.9770/jesi.2018.6.1(10)

Palepu, K.G., \& Healy, P.M. (2013). Business Analysis Valuation: Using Financial Statements, Cengage Learning Australia, South Melbourne, Australia.

Šenková, A. (2017). Kúpelníctvo a kúpel'ný cestovný ruch na Slovensku [Spa and spa tourism in Slovakia], University of Prešov in Prešov, Prešov, Slovak Republic. 